\title{
Factors of Professional Activity of Educators in Pedagogical Practice
}

\author{
Vesna, B. Kravarušici ${ }^{*}$ (D) \\ ${ }^{1}$ The Academy of Applied Preschool Teaching and Health Studies, Kruševac, Department Aleksinac, Republic of Serbia, \\ e-mail: vesna.kljajic@gmail.com
}

\begin{abstract}
The indisputable importance of early learning as well as the accepted documents of international organizations dealing with education have an impact on educational policy in the Republic of Serbia. Systemic solutions support the professional progress of educators/preschool teachers. Clearly limited and publicly recognizable areas of practice, accumulated fund of knowledge acquired through education, experience, which is expanded and deepened by continuous improvement and exchange with the environment; independent and/or cooperative decisions on timely and correct actions; meeting internal and external standards (self / control); ethics in personal and professional life are characterized by professional/competent actions of educators. Factors that modulate the level of competence of educators are the status of society, the immediate social context, the quality of the study program, professional environment, continuous professional development, pedagogical practice, personal characteristics of educators, job satisfaction and private life. The paper critically examines the key elements of the structure of factors in the Republic of Serbia in order to put light on weak points and their improvement. The research of a set of macrosystemic and subsystemic factors points out to the necessity of restructuring, improvement of the quality of selection, basic education of educators, interventions in the offer of trainings in accordance with the real needs of educators. Ensuring an effective, respectful climate in the preschool institution is necessary for microsystem changes. Pedagogical implications are contained in the creation of conditions for the development of participatory relations, critical observation, but also the emancipation and independence of professionally accomplished educators.
\end{abstract}

Keywords: educator/preschool teacher, professional activity, competence, factors.

\section{Introduction}

Educational policy in the Republic of Serbia is aimed at developing conditions for the professional activities of preschool teachers. Society/state has an interest in supporting educators, according to scientific knowledge about the importance of early learning. The results of research by Sammons et al. (2014) show that the quality and scope of time (more than three years) in preschool have a positive effect on the cognitive and social/behavioral development of students. They are reflected in a better start in school and significantly better achievements of children after the first year of schooling. The study Starting Strong 2017: Key OECD Indicators on Early Childhood Education and Care (2017: 146) confirms that the number of years spent in early childhood education and care is a strong predictor of the level of performance achieved in later stages, both in and out of school. The recommendations and decisions of international organizations dealing with education, which directly affect the regulation of the level of preschool education, are also included in the domestic regulations. The tendency is to improve the basic activity of the preschool institution - upbringing and education of children, as well as comprehensive care that includes health-preventive, social protection, care, care and nutrition. The focus is on overcoming the traditional view of educators as a person who takes care of children while their parents are at work. The effects of the quality of pedagogical work of educators should be measurable by a systematically planned and monitored level of reaching the competencies of preschool children. In the recent past, regardless of a couple of reform changes in this level of the educational system, such an evaluation has not been conducted at the level of the Republic of Serbia. Despite that fact, a valid condition for the answer to the set goals of preschool education is, among other things, an educator who professionally performs the planned activities.

In the Dictionary of the Serbian Language, profession is explained as an occupation, vocation, profession; professional refers to the profession, ie, the one who is something by profession (Rečnik "Corresponding author: vesna.kljajic@gmail.com 
srpskog jezika, 2011: 1064). In the Dictionary of Synonyms, profession is equated with service, title, vocation, job, employment, engagement, position, activity, business, furniture, duty, indebtedness, employment, vocation, employment... A professional is one who deals with a job as by his profession, the one who stands out especially in his profession, expert, master, connoisseur, good connoisseur... This interpretation gives value to an occupation that is embodied in emphasizing, coping in the profession (Ćosić et al., 2008: 517). The fact that these are not the only added values is indicated by Bolčićs interpretation in the Sociological Dictionary where it is emphasized that the profession formally implies the highest existing level of education based on scientific and theoretical knowledge, "... requires the acquisition of top expertise, professional competence and authority as a rule, they do not question"(Bolčić, 2007: 48). Professionalism is also linked to standards, practices or motivation within the profession (Encyclopedia Britannica, 2010). Evetts (2007) points out that in recent decades, professionalism has been preferred as a set of competencies, trust and discretion. Professional behavior, according to Yusoff (2009: 2), can be defined as "... the appropriateness of an action or reaction intentionally or unintentionally to changes in the environment or condition or situation that reflect traits associated with his or her responsibilities. In other words, professional behavior is a reflection of professionalism. "

Profession and professional conduct are complementary concepts, but they do not bear identical characteristics. Unlike the profession, where a recognizable occupation is an obligatory and a sufficient condition, professional work in the profession is characterized by: clearly limited and publicly recognizable areas of practice, accumulated fund of knowledge acquired through education, experience, which expands and deepens through continuous improvement and exchange with the environment; independent and / or cooperative decisions on timely and correct actions; meeting internal and external standards (self / control); ethics in personal and professional life. This ensures the acquisition of authority at the level of the institution (interest groups) and the community. What are the factors influencing the formation of a professional educator is a problem that explodes in the work.

\section{Foreign views on the problem of professional activity of educators}

The issue of determining the factors and elements that have a decisive effect on the professional engagement of educators is a relatively new topic (as well as occupation) that preoccupies researchers. The problem of professionalization of occupations in the field of early education was addressed by Boyd (2013), who defines the solution as the need for a higher education, professional development and advanced skills to improve the quality of the program. The results of his research indicate that acquiring professional status and credentials for workers in early education are not enough to keep the most professional and motivated in the field of preschool education, but it is necessary to take steps to significantly improve working conditions, increase salaries and benefits. Boyd points to the lack of observation of the professional status of educators as a personal matrix, drawing attention to the role of society. Butcher and Pletcher (2017) write that the National Association for the Education of Young Children (NAEYC) has prescribed that the establishment of a profession that works to support quality learning for children up to the age of 8 is based on a common purpose, identity and agreement on unique responsibilities and characteristics. They see the support of the profession in legal guidelines, a code of ethics, a set of standards and expectations for practice. In doing so, the set of standards covers various aspects of early education and care, including the learning curriculum, the learning environment, the philosophy of care, and staff support. The authors also identify approaches to teaching young children based on research in psychology, philosophy and education. Among the guidelines for professional behavior of educators are: respect for childhood, child, family, culture, trust in mutual relations, recognition, context, care, upbringing and education, values, commitment... What they emphasize is the unquestionability of safety, health, interests of a child, data confidentiality and cooperation with the family. Analyzing the professional profile of educators, Crosby Kile (2018) points out to four main dimensions of the professionalism of early childhood teachers: professional knowledge, competence, commitment to ethical standards, and personal characteristics. He explains that a professional in the field of early childhood education is someone who has the personal characteristics, knowledge and skills necessary to provide programs that facilitate children's learning. A facilitator is an environment that allows children to learn and grow, to be confident and to gather skills and acquire the skills they will need for later success. He is competent to inform the public about children's and family issues, promote high standards of work and is constantly improving. Educators' presentation/behavior greatly influences public perception of the level of professionalism achieved, according to Crosby Kile. Starting from the premise that professional identity is gradually developed through three complementary steps: education, professional integration 
and performing professional duties with professional development, Androusou and Tsafos (2018: 554) investigated the parameters that influence the formation of professional identity of teachers in preschool education. Tentative findings have shown that professional experience and dominant beliefs about early childhood education are more important for the construction of professional identity than studies. In this research, reflections on the problem include personal characteristics, higher education, knowledge, skills, professional development, respect for ethical and professional standards derived from regulations and competence, as influential ones in the professional activities of educators.

\section{Factors influencing the professionalism/competence of educators}

The starting point for considering the factors that influence the professional activity of educators in the current conditions in the Republic of Serbia is Illeris's theory of learning (Illeris, 2007). The theory considers lifelong learning that takes place through two dynamic and often intertwining processes - interaction and acquisition. The process of interaction is of a social nature, depending on the social and material character of the environment in space and time, thus providing different learning opportunities. Learning takes place on an unconscious and conscious level where the orientation of the individual is an important element. The acquisition process refers to the psychological processing of impulses and influences carried by interaction, building connections with the results of relevant earlier learning. Each learning encompasses three dimensions, two of which take place on a personal level (content, encouragement), through interaction, but always within a broader social system that is crucial for learning opportunities. The richness of content, what is learned, opens a space for acquiring knowledge, understanding, skills that enable the development of insights and functional abilities. Incentives that precede and last during content learning include motivation, emotion, and willpower, ensuring the mobilization of mental energy and maintaining a balance between the physical and the mental health. The tripartite process includes interaction with the social and material environment through immediate situations in the workplace (communication, actions, cooperation) and the general social level, thus achieving integration and sociality. Through acquisition and interaction, through three presented dimensions, it is possible to achieve "functioning appropriately in the different contexts in which we are involved" (TUNING of educational structures in Europe (2006: 4)) or the development of competencies.

Learning seen as the development of competencies suggests specifying this concept. Competences are defined in the TUNING of educational structures in Europe (2006: 4) as "a dynamic combination of cognitive and metacognitive abilities, knowledge and understanding, interpersonal, intellectual and practical skills, as well as ethical values". There is a difference between competence, as a comprehensive, ideal construct of numerous elements, and realized competence. According to Branković (2011), competence refers to the formed ability to perform work. Branković and Popović (2018: 9) believe that there is no competence in the absolute sense, but, "... to a certain extent, they can be developed through education and exercise. Competences in a combination of knowledge, skills, attitudes, motivation and personal characteristics (values, habits, independence, responsibilities) enable active and efficient action in the profession". A high level of achieved competence can be recognized in professional excellence.

Factors of importance for lifelong learning and the realization of a certain level of important competences for the professional activity of educators can be singled out in the manner shown in Figure 1.

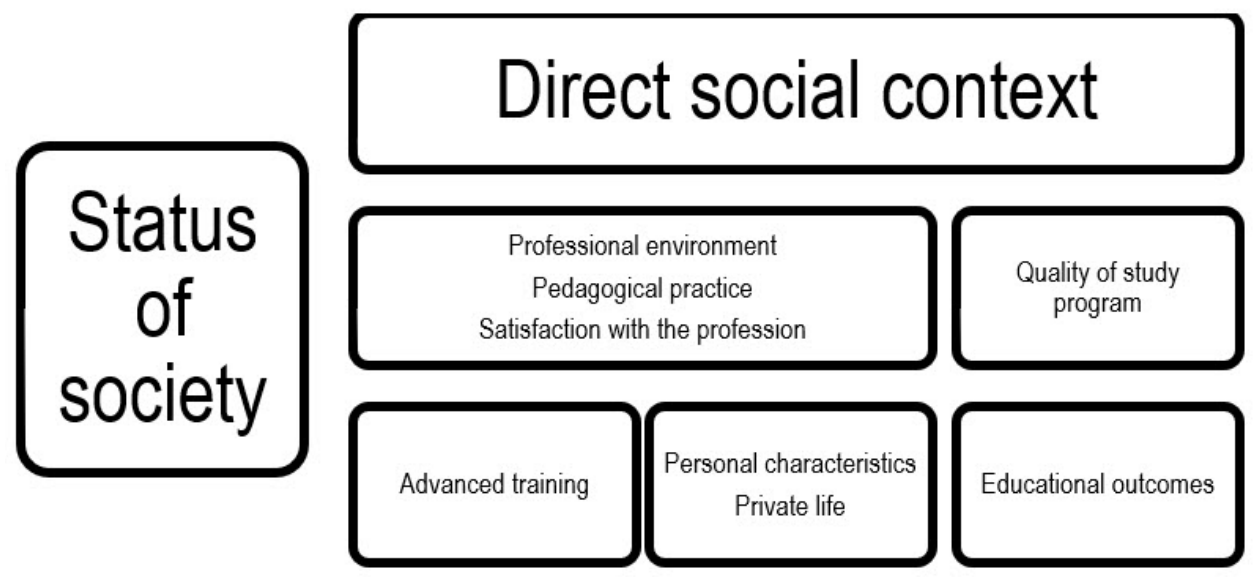

Figure 1. Factors influencing the professional performance of educators 
Within the framework of isolated factors, there are numerous structural elements. Some of the basic ones are:

- Society: organization, economic strength, culture, tradition, position of competent institutions and their systemic functioning, laws and bylaws and their application...;

- Immediate social context: family, resource characteristics of places of growing up, studying, professional work, everyday life-material, economic, cultural, educational, health, social conditions (scope and quality of interactions with family members, relatives, friends, colleagues, children from the group, their parents, contacts with people from the local community, cultural and material goods...);

- Quality of the study program: spatial, material and technical conditions, teaching staff, program (plan, content of the program, modernity of scientific-theoretical sources, balance of theoretical and professional / applied subjects, plan, organization and quality of professional practice, their connections due to transfer and integrity general educational and professional outcomes, individual achievement, ie success in studying...);

- Professional environment: urban, rural, rural environment, type and conditions of work in the preschool institution - private, public; conditional, not in accordance with the prescribed conditions; small, medium, large collective; number of children in the group according to the norm, cooperation with colleagues, local community...;

- Continuous professional development: forms of training, portfolio of professional training as a result of reflection, situational or random...;

- Pedagogical practice: compliance with standards and procedures;

- Personal characteristics: personality structure, its development and dynamics;

- Satisfaction with work and private life.

Factors influencing the professional work of educators are in an overlapping, intertwined and dynamic relationship. Each of them, in addition to universality, also carries certain specifics that arise from a specific social milieu. Due to the extensiveness of the issue, only some of the aspects within the presented factors were analyzed.

\section{Status of society}

Society is an integrated community based on production processes in all areas of human activity, with developed interpersonal relationships depending on the specifics of culture: science, art, education, tradition, religion, the ruling value system (Šušnjić, 1973). "Social institutions are the basis for creating preconditions for general social participation, but also the revitalization and security of citizens, since each of them implies the behavior of all social factors in accordance with assumed values and norms" (Živković, 2013: 24). The Republic of Serbia is a newly established capitalist state, a young democracy with an aspiration to develop civil society and join the European Union (EU). With all the positive developments, it is still on a transitional path, with limited economic powers. Cultural movements are turning from the former Eastern bloc towards Western European achievements and values. Practice in social fields is a mixture of modern and traditional concepts that resist change. In the reform processes since 2000, the Ministry of Education, Science and Technological Development has been established, with a sector that manages preschool education. Strategic developments are aimed at the widest possible coverage of children. According to the data of the Republic Bureau of Statistics (Republički zavod za statistiku, 16.4.2020) in the school year 2019/20. 224,563 children attended preschool education (a significant increase compared to 2016), $76 \%$ of whom were aged from three years to school. The compulsory preparatory preschool program covered more than $97 \%$ of the school-age population.

Historically, the first organized types of gathering of preschool children in our area date from the end of the 18th century (Andrijević, 2012). During this period, preschool institutions were classified into other more developed activities - sometimes educational, sometimes health, and sometimes social (Gavrilović, 2006: 57). In the development of the preschool institution, according to Kopas Vukašinović (2004: 97), the turning point in defining the role of the preschool institution is the adoption of the Program of educational work in the preschool institution in 1969 by the Education Council of Serbia. The goal of preschool education is determined: "... to provide the youngest generation with a healthy and cheerful childhood within the limits of social possibilities and, in accordance with the general educational goals and laws of psychophysical development of the child, to contribute to his proper physical, intellectual, moral and aesthetic education." (Program of educational work in a preschool institution, 1970: 9, according to Kopas Vukašinović, 2004: 98). The process of establishing preschool institutions was accompanied by the regulation of the field of preschool education and the establishment of educational institutions for the education of staff for work 
with small children. Among the first schools for educators, a school was founded in Novi Sad, in 1952, as a four-year, later a five-year high school, then a two-year high school (Andrijević, 2012). Following the social needs, the network of higher schools for educators branched out. Since 2006, in accordance with the Bologna Declaration, the education of educators has been transformed into higher education, lasting three years. To date, the possibility of formal education of educators through academic and professional higher education has expanded. Specialist and master education has been introduced. Changes in the level of education of educators are caused by demands for the transformation of their original roles (guardianship, care) which have diversified into multidisciplinary ones. For a relatively young profession, in order to take the level of professional/competent action of educators, the state has taken action to complete the legislation, as guidelines and obligations. The current situation is that, with the approval of the National Council, numerous laws and bylaws have been adopted, which harmonize the norms with the EU, with little respect for social conditions. Among the basic ones, with annual amendments, are: the Law on Preschool Education (Law on Preschool Education, 2017-2019), as a special law derived from the Law on the Fundamentals of the Education System (Law on the Fundamentals of the Education System, 2017-2020); Rulebook on quality standards of the institution (Rulebook on the quality standards of the work of the institution, 2018); Rulebook on competency standards for the profession of educator and his professional development (Rulebook on standards of competencies for the profession of educator and his professional development, 2018) and Rulebook on the basics of preschool education program (Rulebook on the basics of preschool education programs, 2018). These documents have been harmonized and new foundations have been laid for the work of the preschool institution.

\section{Direct social context}

The Republic of Serbia is characterized by very diverse conditions when it comes to the immediate environmental conditions (developed, middle and poorly developed regions) that preschool institutions have (Municipalities and Regions in the Republic of Serbia, 2020: 304-307). The global tendency of demographic movement of the population from smaller areas to larger cities, lack of funds, causes an imbalance of needs and opportunities. On the one hand, the insufficient capacity of preschool institutions in large centers is verified, but the lack of preschool institutions in smaller areas as well. Considering that local self-governments also participate in the financing of preschool institutions, differences in conditions are evident. The conditions also depend on the awareness of the authorities in the municipalities and institutions about their importance. The government, local governments, international organizations, and civil society organizations are engaged in unifying the environment in which young children grow and develop.

The situation is similar with higher education institutions for educators. The Ministry of Education, Science and Technological Development of the Republic of Serbia is the owner of public higher education institutions. Spatial and material-technical conditions depend on the management of the institution, developed cooperative relations with the competent institution and local government, which differ from institution to institution. It is not unknown that adequate space (sufficient and attractive), good conditions (eg amphitheater equipment, classrooms, exercise rooms, power, flow, open internet access, library fund that qualitatively meets the requirements of the study program and quantitatively the number of students; reading room; teaching aids (scriptorium/bookstore where resources and materials can be provided for monitoring teaching and realization of pre-examination obligations) are some of the factors that favorably affect studying. Although these conditions are different in institutions, as well as in the case of preschool institutions, poorer conditions can be somewhat compensated by the culture of the institution (synergistic fit of individual cultural capitals of employees and students). The guideline for students and associates is the culturally competent practice of employees as "the ability of systems, services and professionals to provide services in an effective and respectful way ..." (Žegarac, Kišjuhas and Koprivica, 2016: 29). The most frequent student interactions take place on a peer-peer realization. Thus, educational experiences are acquired, harmonized and supplemented, but, at the level of the higher education institution, knowledge is conditioned by direct and indirect interactions of the student with the teacher. The main mediators of this interaction are content with encouragement. "Today, the importance of the quality of teachers and their impact on the quality of the educational process and its outcomes are not questioned" (Vranješević and Trikić, 2013: 60). Staff conditions of the institution, ie. the actual capacity of teachers varies. According to the Law on Higher Education (Law on Higher Education, 2020, Article 74), a person who has the appropriate professional, academic, scientific or artistic title acquired in an accredited study program and an accredited higher education institution and the ability to teach can be elected a teacher. In addition to 
the Law on Higher Education, higher education institutions in the field of vocational education take into account the Rulebook on the procedure, evaluation and quantitative expression of scientific research results of researchers (Rulebook on the procedure, manner of evaluation and quantitative presentation of scientific research results of researchers, 2017) when drafting internal acts, additionally defining the profile of teachers' competencies. Ability to teach is assessed on the basis of the results shown by the candidate in working with students (often without defined criteria). Evaluation of pedagogical work of teachers by students is measured quantitatively or qualitatively (depending on how the institution has structured the instrument) and not always regularly. Scales for scientific/professional papers published in scientific/professional journals or collections of reviews from the scientific or professional field for which the teacher is selected are set differently. In some institutions they are specified in one, two, three or five papers for the election period, in some the number is not specified. The framework of the national categorization to which the work should belong is usually missing. When choosing a teacher for the title (lecturer, senior lecturer, professor of vocational studies), the reference of papers for subjects that the teacher realizes within the study program is not always taken into account, which opens the possibility for abuse. Sometimes conditions included are: providing professional youth, contribution to improving the quality of work of the institution, contribution to the academic and wider community, participation in domestic and international projects, participation or conducting special professional courses, seminars or workshops in the country and abroad; leadership or engagement in national or international scientific or professional organizations and the like. For now, the very accreditation of the study program confirms the quality of the existing teaching staff.

However, the quality of teachers cannot be assessed only on the basis of qualifications (formal education, scientific field/narrow field). Quality defines the value system of teachers, didactic-methodical knowledge, pedagogical experience, personal characteristics, work style, communication and attitude towards students, continuity, quality and readiness to implement the knowledge acquired through training, scientific and professional references. Few studies draw attention to this problem. The ATEPIE project (2013) defines "professional development and responsibility for professional development" as an area that consists of "skills and values that teachers assess as the ones that are most lacking." (Vranješević and Trikić, 2013: 62). Đukić (2010: 144) emphasized that "no higher education reform will meet expectations, nor will it reach the set goal, if pedagogical-didactic issues of modernization of higher education itself, including various didactic innovations, do not become a priority." Miočić (2017: 73) states that "at all previous levels of education, in order to work in teaching, it is obligatory to attend programs that ensure the acquisition of basic pedagogical-psychological and methodological-didactic knowledge." Trivunović also recommends (2017: 129) creating the program of specialization that would be dedicated to developing the communicational competences as well. Research by Babić Kerkez (2011) indicates that the educational needs of teachers and associates at the faculty for knowledge in pedagogy, didactics and methodology exist. The need for contents from pedagogy and methodology grows with a higher title and a longer length of service, while the need for contents from didactics decreases.

In practice, apart from teachers in the field of pedagogical and andragogical sciences and teachers who have prepared themselves for the teaching profession at some level of higher education, a large number of teachers do not have a fundamental basis for the teaching profession / work with students. They rely on the personal experience of the teaching function within the system, known models, exchange of experiences, which results in implicit pedagogies. Standards for the work of teachers (Rulebook on standards and procedure for accreditation of study programs, 2021) have recently been applied at the level of higher vocational education. This insufficiently and inadequately regulated resource of a higher education institution is in the process of external regulation by reforming higher schools into academies and, in relation to the current situation, is slow and tolerant.

When it comes to programs for the education of educators, in addition to general pedagogy, the backbone consists of relatively young pedagogical sciences, such as family pedagogy, preschool pedagogy, general and special methods of educational work. Unlike the initial unified bases, from the application of the Bologna rules, the study programs of basic studies through which educators of preschool children are educated are variously structured. This phenomenon is in line with the document TUNING of educational structures in Europe (2006), based on the approach of developing, restructuring, developing, implementing and evaluating study programs. The TUNING project supports differences in study programs in the same field, but works to provide common reference points, in order to ensure their comparability in Europe. In the set of reference points, the competencies that students acquire are emphasized: general (generic) and professional (subject specific). General competencies include:

- Instrumental: cognitive abilities, methodological abilities, technological abilities, language skills;

- Interpersonal: individual abilities, e.g. ability to communicate and cooperate; 
- Systemic: abilities and skills related to entire systems: a combination of understanding, sensibility and knowledge ... (Introduction to harmonization (TUNING) of educational structures in Europe, 2006: 12), which are cumulative in nature compared to the previous ones.

One dimension of the problem of acquired competencies during studies is illuminated by a look at the curricula of study programs for educator education. This opens a dilemma: is it possible for educators to master general competencies in the formal system. The standards for study programs of basic vocational studies prescribe the size of participation in general education (about 15\%), professional (about 40\%) and professional-applied (about 45\%) subjects (Rulebook on standards and procedure for accreditation of study programs, 2021). The prescribed setting of the study program does not support the development of general competencies, while the existing general education subjects are often an inadequate basis for the development of general competencies of students. The second dimension is the construction of the study plan, which includes subjects that do not follow scientific diversification (from general sciences, to special, specialized, interdisciplinary, multidisciplinary). The setting of the subject in the plan is also conditioned by the personnel possibilities of the higher education institution.

Krnjaja (2019: 21) believes that "it is necessary to prepare a practitioner through initial education, who in addition to conceptual and functional knowledge has a critical, reflective attitude towards their own practice, within the sociocultural approach to education of future primary school teachers and educators." He proposes continuous changes in the study program, shifting the focus to the learning process, research instead of teaching, overcoming the gap between theory and practice, opening a higher education institution, establishing a partnership between students, teachers and practitioners.

However, the study programs of levels one and two, and approved by the National Body for Accreditation and Quality Assurance in Higher Education of Serbia (NAT), represent only something more than a basic support for the profession of educator, in relation to the requirements of the profession.

In the process of selection when enrolling future educators in basic studies, the requirements that were set in the middle of the last century (spiritual and physical health, to have hearing) were not moved away. In addition to completed secondary education, of any field /educational profile/occupation, candidates for enrollment pass a test of speech, music and physical abilities and take a classification exam (Serbian language, general culture and information). The interest of higher education institutions for educators is self-preservation (in the absence of a network of institutions in line with market needs). The most basic rules are followed during the enrollment procedure. However, regardless the scientific knowledge about the importance, there is no question of examining the personal characteristics of candidates that are desirable for working with children and the initial abilities needed for further development of prescribed competencies of educators (as well as in many other areas which involve working with people).

\section{Professional environment}

By completing the formal, higher vocational/academic education and entering the world of work, the process of professional development of educators begins, which flows through pedagogical practice, with which it is in a reversible relationship. The diversification of the network of preschool institutions, the possibility of establishing private ones, the coverage of children with preschool education and the removal of restrictions on employment in the public sector have influenced the higher capacity of hiring educators, applying and starting professional work. The teams of preschool institutions are small, medium and large. Private institutions mostly belong to the group of small collectives, with a low number of students and educators who perform tasks that go beyond the scope of the educator's workplace. Public institutions are territorially connected to municipalities, branched, with several calendar and mixed groups of children, facilities/departments and larger collectives (Municipalities and Regions in the Republic of Serbia, 2020: 304-307). In larger environments, material and cultural wealth provides the opportunities for direct natural and social contacts of children with various resources within the educational work. Numerous teams open up greater opportunities for the exchange of professional work experiences.

\section{Continuous professional development}

Recognized and standardized as a necessary part of the professional development of educators, continuous professional development includes numerous forms. It takes place through formal, non-formal and informal education. Educators self-selectively use the opportunity to improve the level of their formal education within the higher education system (specialist, master studies). "The key feature of non-formal education is flexibility and it enables the acquisition of various skills and competencies, through activities 
such as seminars, lectures, conferences and workshops (Pavićević and Petrović, 2015: 103)." This includes the activities of educators within the institution: action research, mutual exchange of experiences, examples of good pedagogical practice, work in professional bodies, promotion of preschool activities, preparation of professional papers, attending trainings approved by the Institute for the Advancement of Education. These forms are planned within the institution. The findings of the research conducted by Gutvajn (2017: 34) show that "almost half of educators state that attending seminars, which are organized in the institution, is the most common type of professional development of employees." It is about the approved trainings for a particular group of educators held in the institutions due to efficiency and cost reduction. In this way, greater availability of training, coverage of educators and the realization of a certain number of points to the educator on the basis of professional development is provided. The training offer does not cover all areas of educators' work (see the Catalog of Professional Development Programs/ Katalog programa stručnog usavršavanja, 2018-2021). The authors of the trainings are mostly fellow educators. Educators have already had the opportunity to get to know some of the examples of positive pedagogical practice during the gatherings of the professional association. The obligation to participate in trainings affects the motivation of educators (and the result). For the selection of national training, the basis should be professional portfolios of educators, resulting from self / evaluation and individual needs for specific topics.

Gutvajn (2017: 34) states that one third of educators "improve outside the institution (summer I winter schools, forums, meetings, reading and analysis of professional texts and manuals)." At the same time, thanks to the development of information technology, incidental, unintentional, unintentional learning, due to its accessibility (a large number of electronic sources), relevance at a certain moment of pedagogical practice and freedom of choice of the researcher, gained a significant place in the process of individual professional development.

\section{Pedagogical practice or competence and achieved level of competence}

In order to improve the work of the preschool institution, the areas of quality are marked, primarily educational work, then, support for children and families, quality management and organization (Rulebook on quality standards of the work of the institution, 2018). The key carrier in all areas is the educator. The area of quality refers to the preschool institution as a professional learning community, which includes professional communication, teamwork, as the indicators that are achieved through the process of informing about all issues that are important for the institution. According to the research, Rakić, Stojadinović and Čolović (2017: 70) play an important role in achieving a higher level of quality in the work of educators "more active role of employees in business processes, taking responsibility for business improvement and greater authority of employees to make decisions of greater importance ... for what the integration and interconnection of organizational structure, procedures and resources are needed ", in order to realize quality management. The application of digital technologies is also an indicator for the area of quality. Modern communication and information technologies are an integral part of the lives of young children. This cannot be said for educators, so their implementation in work is less pronounced. Smieško Bokanić et al. (2019: 5-6) as preliminary results of the research of educators' attitudes on the application of the Basics of Education Program (Basics of preschool education programs - Years of takeoff, 2018) state that educators: mostly agree that new technologies are necessary, that it is needed pay attention more to "information education", and that the exchange of experiences of educators contributes to the development of competencies for the application of technology. Educators are mostly able to search the Internet, $67 \%$ of educators exchange information via e-mail or social networks. More than half of the surveyed educators are able to communicate with other educators through online collaboration systems in order to access the materials that have been created. Educators use digital technologies in their work. Media resources are mostly used to plan learning activities, collaborate with colleagues and follow blogs intended for educators. Modern communication and information technologies, whose consumers are children from an early age, still do not reach educators at the same pace, and their representation in educational work is less pronounced. Research by Mesaroš Živkov et al. (2019: 39) shows that the largest number of educators sometimes use the Internet, TV programs and computers in the preparation and implementation of activities with children. In the current time (covid pandemic19), situationally conditioned, educators have advanced in the use of ICT as well. The area of quality determines the establishment and maintenance of cooperation with all institutions important for the implementation of the preschool program. In the second year of successive implementation of the new program, educators devote most of their time to the implementation of projects in which children participate (Smieško Bokanić et al., 2019: 
5-6) and spend the least time involving children in local projects, events and activities and cooperation with colleagues from other institutions for the purpose of exchanging experiences, joint learning and research.

The standard in this area also refers to fostering a climate of trust and togetherness. It was explained through indicators such as respect for the norms for exercising rights and responsibilities, joint work of different professions, exchange of experiences and respect for the perspectives of the participants in the construction of the vision of the development of the institution. Achieving the standard of developing a culture of self-evaluation is recognized through reflective, research and critical review of one's own competencies and practice (Rulebook on quality standards of the work of the institution, 2018). Selfassessment is a short-term practice, still developing. Obstacles are established, models of work, limited types and use of objectified instruments, centeredness of educators ... In support of the claim are the findings of the research that will be presented below.

The standard by which the institution becomes a place of continuous change is considered on the basis of the previous standard and its indicators, with the addition of professional training in accordance with the needs of employees. The latest standard in the field of professional learning community is characterized by a public action and activism in the community, in order to stimulate the visibility of the profession, promote the institution and cooperate with relevant institutions from the local environment, already appointed in the field of direct educational work (Rulebook on quality standards of the work of the institution, 2018).

The professional profile of educators is characterized by a multitude of roles. The self made one (as a characteristic of the personality) changes the structure of the institution into an open system, and is the creator of a participatory atmosphere, is a teammate of children, interesting, cheerful, supports their independence, directs them, develops their social skills (assuming he has his own - author's comment), encourages the development of self-control, initiative, constructive discussion, with a partnership and non-authoritarian attitude. He is able to observe children, follow them, adapt the plan to their needs, implement and evaluate educational work - children's achievements, his own achievements, develop the program. He is reflexive and critically evaluates the results of his own work. It exchanges assessed values within the team of educators, through a democratic debate, as a type of additional verification (Rulebook on standards of competencies for the profession of educator and his professional development, 2018). The educator realizes his professional role through direct work with children ("learning and development support focused on well-being through relationships and sharing"), program development ("planning, joint program development, monitoring, documenting, evaluating"), professional development ("reflective practice"), horizontal learning, networking, professional development" and professional public action ("advocacy, promotion, contribution, initiation of actions") (Fundamentals of preschool education programs, 2018: 34). By defining these three areas of competence of educators, the corresponding professional knowledge, skills and values are determined. For the fulfillment of the level of standards, as well as the competence of educators, internal (self-evaluation) and external models (external evaluation) of monitoring are envisaged.

Empirical research of the segments of pedagogical practice that are an integral part of the competencies of educators in recent years signals a discrepancy between the prescribed and the real one. The research findings (Gutvajn, 2017:34) show that the largest number of educators (85\%) have a positive image of themselves as professionals, as well as to recognize their "good" and "bad" traits. The majority of educators $(77 \%)$ stated that they feel qualified to gather relevant professional information, as well as to use different sources and methods of gathering information in the field of educational work (for example, horizontal learning - "learning from each other"). The author states that the changes in the education system of Serbia have "encouraged a significant number of educators to develop their own practice and professional competencies." How realistic is the self-assessment of educators, further results show. The attitudes of students, future educators, about democratic values (Kravarušić, 2014: 376) indicate that the majority: do not accept the basic postulates of democratic decision-making if they are contrary to personal attitude $(67.8 \%)$; does not accept teachers as a dyad partner/as a potential collaborator in the process of their formation as educators (58.6\%); less than half of the respondents are not for socializing with peers of other nationalities (43.5\%) and express disagreement with attitudes that support multiculturalism in any form. The obtained results are contrary to the generationally expressed positive tendencies of accepting equality, and thus diversity of each kind. Such attitudes can have an adverse effect on the future actions of educators, especially with children from vulnerable groups. Students are reluctant and show a lack of responsibility for performing team tasks if it does not fit into their personal agenda (39.1\%). They believe that active participation is not significant (38.7\%). The research that Marković (2014) conducted with students and future educators indicates that students express beliefs about the child that are close to 
modern scientific knowledge, but their approach is closer to the traditional one. The transfer of identified attitudes to the sphere of professional work is also stated by Zlatković and Ristić (2019: 65). "... implicit beliefs are deeply rooted in the thought process, partly because once established implicit beliefs form the frameworks from which new information and experiences are built and evaluated. New information that supports implicit beliefs is easier to notice and accept than information that is opposed to it. "As educators, former students fit into the dominant patterns of work in preschool (Kravarušić, 2019: 108). Colić (1997) explains that educators dominantly perceive the child through a mixture of modern and traditional attitudes: as active, curious, free, spontaneous, creative (with differences in such attitudes and pedagogical behavior), fun and affectionate (traditional approach), while in response the child's needs for tenderness and support are recognized by the difference in the educator's attitude and practical behavior. Miškeljin (2012: 4) states that the way in which educators understand and interpret the curriculum (formal program as an official text or "active" program, or what happens and constructs in the specific context of educational practice) depends on their implicit pedagogies, knowledge, beliefs and assumptions they have about the program, the child and their own role. "In the research of direct educational work (Kravarušić, 2016: 524). Educators have proven to be a limiting factor in the process of choosing the type of activity, following the plan and program of work, with a low degree of respect for children's initiative, choices, interests and needs. During communication with children, they send messages, the characteristic ones of which belong to the groups of regulatory, conditioning and stimulating, which do not express a personalized approach and close opportunities for developing the communication process in the interpersonal educatorchild relationship. In more than half of the monitored educators, the roles of managing discipline and organization of the educational process were detected as the most represented roles, where only a fifth of educators dedicate themselves to creating respectful interpersonal peer relationships and relationships between educators and children. External motivation of children is stimulated mainly by visual materials for work, which are used in the dominant frontal form of work, along with verbal methods. Contrary to the beliefs of educators, the influence on the development of the intellectual sphere is not sufficiently represented. The most frequent are creative and physical activities (Kravarušić, 2019: 107). In the applied research Mišić (2017), speech, drama, art, music and dance activities were singled out as the most represented $(33.33 \%)$. It is important to note that a longitudinal study conducted by Baker et al. (2015) found that preschool teachers have an important impact on children's academic performance, and that teachers 'misperceptions about children's academic skills could have negative consequences, especially for preschoolers from economically deprived backgrounds. In light of these indicative findings and the newly established regulatory documents for the work of educators, intensifying research on the real level of competence of educators would contribute to isolating weaknesses and taking actions aimed at their further development. Miškeljin (2016: 395) also states: "In line with modern understandings and research on professional development, which indicate the fact that training professionals is not enough if we want to create sustainable change."

\section{Personal characteristics}

The structure of the personality consists of a relatively permanent, complex and special organization of the basic building blocks of the personality (Trebješanin, 2001: 468), such as ability, temperament, character, motives, interests, attitudes, values, etc. In relation to the measure and quality of the influence of hereditary factors, environment and personal activity, dynamic developmental processes take place that characterize the individual. The characteristics of educators that are considered positive and socially acceptable are openness, altruism, empathy, tolerance, consistency, responsibility, critical attitude, perseverance and the like. They are joined by traits "such as motivation or the lifestyle of the educator" (Radovanović, 2019: 82). In professional work, they are reflected through a dominantly recognizable performance in relation to children and associates (authoritarian, anarchic, democratic style, according to Kamenov, 2006). It should be noted that the choice and existence in the profession of educator is not always a process that lasts driven by the internal motivation of the person for the profession. It can be conditioned by the current attractiveness of the occupation, limited offer, achieved educational achievement, acting along the line of least resistance, conformism, acquisition of life circumstances, existential and other reasons. The degree of influence of all explained factors on the educator depends on the accumulated knowledge, in addition to the personal characteristics of the educator (eg focus on available stimuli, resilience, level of neuroticism ...). 


\section{Job satisfaction and private life}

On socially recognized mastery of the profession, as in other activities, feedback on work have achieved job satisfaction and private life. Although one should rationally separate these two aspects of life, man is a socio-emotional being and such distancing will depend on the established usages of personal control. In larger environments, due to the lower frequency of social interactions and alienation, there are greater opportunities for this. Examinations of this problem (Matanović, 2009: 335) distinguish two predictors. Pleasure (higher score-higher pleasantness) is attributed to people who are good-natured, cooperative, nurture friendly relationships with other people, adopt norms from multiple sources, and easily fit into the work environment. The second, most common predictor is neuroticism (high score-low satisfaction). People with pronounced neuroticism find it harder to adapt, often clash with co-workers and authority, recover significantly longer from stress, are prone to violent reactions and "experience negative emotions in all spheres of life." In the research Mirković and Čekrlija (2015: 213) as a significant predictor of overall job satisfaction, neuroticism was singled out (especially for aspects: salary, nature of work and communication). "Extraversion and pleasure for the aspect of associates, conscientiousness for the aspect of the nature of work" were also singled out. The authors conclude that "the results obtained have significant implications for selection procedures and human resource management practices." From the received results, it could be hinted that in order to decrease the risk of being unsatisfied with the job and private life, there should be a psychological test for the enrollment of candidates in higher education institutions that educate educators.

Finally, considerations of factors that model the professional character of educators would not be complete without emphasizing the existence of professional integrity ("honesty, reliability, sound thinking, maintaining professional boundaries, lifelong learning and training, etc.", Žegarac, Kišjuhas and Koprivica, 2016: 36), without which the educator would be reduced to a technical executor of the activity of upbringing and education.

\section{Conclusion}

Exploring the problems of macrosystem and microsystem factors and their subsystems indicates the complexity, dynamism and differences in the level of influence on the professional/competent actions of educators. The efforts of the society/state on the regulation of the system of preschool education are evident. The contribution of macrosystem factors would be more effective by restructuring: networks of higher education and preschool institutions in line with the needs of the market and parents, which would provide an opportunity to equalize material conditions. Strengthening the monitoring of the application of legislation and evaluation of the outcomes of preschool education after the introduction of the preschool program at the national level would provide clear indicators of the value of the program, the work of educators and weak points. The introduction of the state obligation for acquiring knowledge from pedagogical sciences would contribute to the quality of higher education teaching staff, as well as clearly specifying the criteria for the selection and monitoring of the quality of teachers. Redesigning study programs, with an emphasis on introducing more subjects, would support the development of students' general competencies. Expanding the qualification process by introducing a psychological examination and determining the limits of previous school success would affect a better selection of candidates for enrollment in the study program for educator education. The setting of compulsory professional development should be adjusted to the needs of educators, based on the portfolio of professional development, by introducing thematic units that arise from direct educational work: human and children's rights, psychological, didactic-methodological knowledge, communications and ICT, work evaluation. At the microsystem level, improvements can be expected by involving educators in considering and deciding on the work of the institution, encouraging reflexivity, teamwork, self-evaluation process, developing pleasant relationships and rewarding according to jointly conceived rules. These would also be recommendations from the presented analysis.

\section{Conflict of interests}

The author declares no conflict of interest. 


\section{References}

Andrijević, S. (2012). 60 godina škole za obrazovanje vaspitača u Novom Sadu. [60 years of preschool teacher education in Novi Sad]. Novi Sad: Visoka škola strukovnih studija za obrazovanje vaspitača. Retrieved from https://www.vaspitacns. edu.rs/index.php?option=com_content\&view=article\&id=255\&ltemid=180

Androusou, A. \&Tsafos, V. (2018). Aspects of the professional identity of preschool teachers in Greece: investigating the role of teacher education and professional experience. Teacher Development. An international journal of teachers' professional development. 22(4), 554-570. https://doi.org/10.1080/13664530.2018.1438309

Babić Kerkez, S. (2011). Samoprocena obrazovnih potreba nastavnika. [Self-assessment of teachers' educational needs]. Tehnologija, informatika i obrazovanje za društvo učenja i znanja. 6. Međunarodni simpozijum: Čačak, Tehnički fakultet. Retrieved from http://www.ftn.kg.ac.rs/konferencije/tio6/radovi/3)\%20Nastavnici\%20i\%20skola\%20u\%20 informaciono-tehnoloskom\%20okruzenju/PDF/308\%20Snezana\%20Babic\%20Kekez.pdf

Baker, C. N., Tichovolsky, M. H., Kupersmidt, J. B., Voegler-Lee, M. E., \& Arnold, D. H. (2015). Teacher (mis)perceptions of preschoolers' academic skills: Predictors and associations with longitudinal outcomes. Journal of Educational Psychology, 107(3), 805-820. https://doi.org/10.1037/edu0000008

Bolčić, S. (2007). Profesija U Mimica A., Bogdanović M. Sociološki rečnik. [Profession. Sociological dictionary]. Beograd: Zavod za udžbenike.

Boyd, M. (2013). "I love my work but..." The Professionalization of Early Childhood Education. The Qualitative Report, 18(36), 1-20. https://doi.org/10.46743/2160-3715/2013.1470

Butcher, K. \& Pletcher, J. (2017). Professionalism in early childhood care and education. Michigan State University Extension, Lansing Community College. Retrieved from https://www.canr.msu.edu/news/professionalism_in_early_childhood_ care and education

Branković, $\bar{D} .(2011)$. Definisanje kompetencija nastavnika razredno-predmetne nastave. [Defining the competencies of classroom teachers]. Nova škola. 8(11). Bjeljina: Pedagoški fakultet.

Branković, D. \& Popović, D. (2018). Profesionalne kompetencije nastavnika razredne nastave. [Professional competencies of primary school teachers]. Banja Luka: Naša škola, (1), 7-26. https://doi.org/10.7251/nsk1801007b

Colić, V. (1997). Dečje jaslice - gledane iz antropološkog ugla. [Nursery - viewed from an anthropological angle]. Beograd: IPA Filozofskog fakulteta.

Crosby Kile, N. (2018). I'm a Teacher, not a Babysitter!: Professionalism in Early Childhood. Early Childhood Education. Article 22776. Retrieved from https://www.continued.com/early-childhood-education/articles/i-m-teacher-not-babysitter-22776

Ćosić, P. \& saradnici. (2008). Rečnik sinonima. [Dictionary of synonyms]. Beograd: Kornet.

Đukić, M. (2010). Nova paradigma univerzitetske nastave kao izraz pedagoške reforme visokog obrazovanja. [A new paradigm of university teaching as an expression of pedagogical reform of higher education]. Sociološka luča, IV(1), 135-145.

Evetts, J. (2007). Professionalism. Encuclopaedia Britannica. Retrieved from https://www.britannica.com/topic/professionalism

Gavrilović, A. (2006). Multifunkcionalna delatnost predškolskih ustanova. [Multifunctional activity of preschool institutions]. Nastava i vaspitanje, 55(1), 57-69. Retrieved from http://scindeks.ceon.rs/article.aspx?artid=0547-33300601057G

Gutvajn, N. (2017). Upravljanje ličnim profesionalnim razvojem iz perspektive vaspitača. [Managing personal professional development from the educator's perspective]. U: Malinić, D. \& D. Vesić (ur.). Knjiga rezimea sa XXI naučne konferencije nacionalnog značaja. Pedagoška istraživanja i školska praksa. Obrazovne promene u Srbiji: izazovi i perspektive. Institut za pedagoška istraživanja, Ekonomski fakultet Univerziteta u Beogradu, ZUOV i ZVKOV, 33-34.

Illeris, K. (2007). How We Learn. Learning and non-learning in school and beyond. London, New York: Routledge- Taylor \& Francis s e-Library.

Kamenov, E. (2006). Opšta metodika: vaspitno-obrazovni rad u dečijem vrtiću. [General methodology: educational work in kindergarten]. Novi Sad: Dragon.

Katalog programa stručnog usavršavanja za školsku 2018/2019, 2019/2020. i 2020/2021. godinu. [Catalog of professional training programs for the school year 2018/2019, 2019/2020. and 2020/2021. Year]. Zavod za unapređivanje obrazovanja i vaspitanja. Retrieved from https://zuov-katalog.rs/?action=page/catalog

Kopas Vukašinović, E. (2004). Karakteristike i razvoj programa za predškolsko vaspitanje i obrazovanje u Srbiji. [Characteristics and development of programs for preschool education in Serbia]. Doktorska disertacija. Univerzitet u Novom Sadu, Filozofski fakultet. https://doi.org/10.2298/ns20041113kopasvukasinovic

Kravarušić, V. (2014). Stavovi budućih vaspitača o demokratskim vrednostima. [Attitudes of future educators about democratic values]. U: Jokovic, M. (ur.). Naše stvaranje. Deseti simpozijum sa međunarodnim učešćem "Vaspitač 21. veku“. 30,31.3.2013. Sokobanja: Aleksinac: Visoka škola za vaspitače strukovnih studija, (14), 372-380.

Kravarušić, V. (2016). Participacija dece u aktivnostima predškolske ustanove - percepcija studenata. [Participation of children in the activities of the preschool institution - student perception]. Novi Sad: Pedagoška stvarnost, LXII(3), 513 - 528. Retrieved from https://pedagoskastvarnost.ff.uns.ac.rs/asb/2016/PS-3_2016.pdf

Kravarušić, V. (2019). Uticaj zakonskih novina na vaspitno-obrazovni rad u predškolskoj ustanovi. [Influence of legal innovations on educational work in a preschool institution]. U: Radunović Stolić, D. (ur.). Doprinos predškolstva ostvarivanju ciljeva obrazovanja i vaspitanja. Cetrnaesta konferencija „Vaspitač u 21. veku“, 28,29.3.2018. Sokobanja: Aleksinac: Visoka škola za vaspitače strukovnih studija, (18), 99 - 112. Retrieved from http://media.vsvaspitacka.edu.rs/2019/03/Zbornikaleksinac-sa-udk_5-3-19.pdf

Kravarušić, V. (2020). Ka profesionalizmu u predškolskoj ustanovi. [Towards professionalism in the preschool institution]. U: Jašović, P. (ur.). Značaj kompetentnosti vaspitača za kvalitet vaspitanja i obrazovanja dece predškolskog uzrasta. Zbornik radova sa Petnaeste konferencije sa međunarodnim učešćem Vaspitač u 21. Veku. Akademija vaspitačkomedicinskih strukovnih studija, Odsek Aleksinac, (19),111-117. Retrieved from http://media.vsvaspitacka.edu. rs/2020/05/Zbornik-2020sredjen_print-merged.pdf

Krnjaja, Ž. (2019). Visokoškolska ustanova i dečiji vrtić kao partneri: od vežbaonice ka zajednici učenja. [Higher education institution and kindergarten as partners: from the gym to the learning community]. U: Pavlović Breneselović, D., Stepić, G., Prlić, I. (ur.). Inicijalno obrazovanje i stručno usavršavanje vaspitača-partnerstvo u građenju kvaliteta. Zbornik radova 
sa 2. Međunarodne naučno-stručne konferencije. Sremska Mitrovica: Visoka škola strukovnih studija za vaspitače i poslovne informatičare- Sirmium, 13-28. Retrieved from http://sm-vaspitac.edu.rs/wp-content/uploads/2019/11/ Zbornik-radova-elektronska-verzija-2019.pdf

Marković, T. (2014). Model integrativne prakse u inicijalnom obrazovanju vaspitača. [Model of integrative practice in initial education of educators]. Doktorska disertacija. Beograd: Filozofski fakultet Univerziteta u Beogradu. Retrieved from https://nardus.mpn.gov.rs/bitstream/handle/123456789/3343/Disertacija.pdf?sequence=6\&isAllowed=y

Matanović, J. (2009). Osobine ličnosti kao prediktori zadovoljstva poslom. [Personality traits as predictors of job satisfaction ]. Primenjena psihologija, 2(3), 327- 338. https://doi.org/10.19090/pp.2009.4.327-338

Mirković, B. \& Čekrlija, Đ. (2015). Karakteristike ličnosti zaposlenih i zadovoljstvo poslom. [Personality characteristics of employees and job satisfaction ]. Radovi, časopis za humanističke i društvene nauke, 22(22): 213-230. https://doi. org/10.7251/rad1622013m

Mesaroš Živkov, A., Mićević Karanović, J., Pavlov, S. \& Brkljač, T. (2019). Digitalni mediji i didaktičke inovacije u radu vaspitača. [Digital media and didactic innovations in the work of educators]. Pedagoška stvarnost, LXV(1), 31-44. https://doi. org/10.19090/ps.2019.1.31-44

Miočić, I. (2017). Nastavničke kompetencije sveučilišnih nastavnika: izazovi i očekivanja. [Teaching competencies of university teachers: challenges and expectations]. Školski vjesnik: časopis za pedagogijsku teoriju i praksu, 66(1), 63-76. Retrieved from https://hrcak.srce.hr/186828

Miškeljin, L. (2012). Kurikulum iz perspektive vaspitača. [Curriculum from the perspective of educators]. Doktorska disertacija. Filozofski fakultet Univerziteta u Beogradu. Retrieved from http://doiserbia.nb.rs/phd/fulltext/BG20120921MISKELJIN. pdf

Miškeljin, L. (2016). Mentorstvo kao kolaboracija praktičara - perspektiva mentora. [Mentoring as a collaboration of practitioners - mentors' perspective]. Nastava i vaspitanje, LXV(2), 395 -410. https://doi.org/10.5937/nasvas1602395m

Mišić, J. (2017). Vaspitanje i obrazovanje dece predškolskog uzrasta. [Upbringing and education of preschool children]. Specijalistički završni rad. Aleksinac: Visoka škola za vaspitače strukovnih studija.

OECD (2017). Starting Strong 2017: Key OECD Indicators on Early Childhood Education and Care, Starting Strong, OECD Publishing, Paris, https://doi.org/10.1787/9789264276116-en

Opštine i regioni u Republici Srbiji. [Municipalities and regions in the Republic of Serbia].(2020). Gavrilović, D. (ur.). Beograd: Republički zavod za statistiku. Retrieved from https://publikacije.stat.gov.rs/G2020/Pdf/G202013047.pdf

Osnove programa predškolskog vaspitanja i obrazovanja - Godine uzleta. [Basics of preschool education programs - Years of take-off]. (2018). Retrieved from https://ecec.mpn.gov.rs/wp-content/uploads/2020/02/OSNOVE-PROGRAMA-.pdf

Osnove programa predškolskog vaspitanja i obrazovanja [Fundamental of preschool education programs] (2018). Retrieved from https://ecec.mpn.gov.rs/wp-content/uploads/2020/02/OSNOVE-PROGRAMA-.pdf

Pavićević, M. \& Petrović, D. (2015). Razlike između formalnog, neformalnog i informalnog obrazovanja. [Differences between formal, non-formal and informal education]. Zbornik radova Učiteljskog fakulteta, (9), 103-113. https://doi.org/10.5937/ zrufpl1509103p

Pravilnik o standardima kvaliteta rada ustanove.[Rulebook on the quality standards of the work of the institution]. (2018). Službeni glasnik RS - Prosvetni glasnik, (14).

Pravilnik o standardima kompetencija za profesiju vaspitača i njegovog profesionalnog razvoja.[Rulebook on standards of competencies for the profession of educator and his professional development].(2018). Službeni glasnik RS - Prosvetni glasnik, (4).

Pravilnik o osnovama programa predškolskog vaspitanja i obrazovanja. [Rulebook on the basics of preschool education programs]. (2018). Službeni glasnik RS - Prosvetni glasnik, (16).

Pravilnik o postupku, načinu vrednovanja i kvantitativnom iskazivanju naučnoistraživačkih rezultata istraživača. [Rulebook on the procedure, manner of evaluation and quantitative presentation of scientific research results of researchers]. (2017). "Sl. glasnik RS", 24/2016, 21/2017 i 38/2017.

Pravilnik o standardima i postupku za akreditaciju studijskih programa. [Rulebook on standards and procedure for accreditation of study programs]. (2021). "Službeni glasnik RS", 13/2019, 1/21. Retrieved from http://www.pravno-informacionisistem.rs/SIGlasnikPortal/eli/rep/sgrs/drugidrzavniorganiorganizacije/pravilnik/2019/13/7/reg

Predškolsko vaspitanje i obrazovanje. [Preschool education]. (16.4.2020). Republika Srbija, Republički zavod za statistiku. Retrieved from https://www.stat.gov.rs/oblasti/obrazovanje/predskolsko-vaspitanje-i-obrazovanje/

Professional. Professionalism. Encuclopaedia Britannica (2010). Retrieved from https://www.britannica.com/search?query=+ professional+meaning\&engine $=$ bss

Radovanović, N. (2019). Profesionalni razvoj i stručno usavršavanje vaspitača predškolskih ustanova. [Professional development and training of preschool teachers]. Sinteze, (15), 79-91. https://doi.org/10.5937/sinteze8-21173

Rakić, A., Stojadinović, D. \& Čolović, M. (2017). Uticaj motivacije zaposlenih na kvalitet rada u predškolskoj ustanovi. [The influence of employee motivation on the quality of work in preschool]. U: Malinić, D. \& D. Vesić (ur.). Knjiga rezimea sa XXI naučne konferencije nacionalnog značaja. Pedagoška istraživanja i školska praksa. Obrazovne promene u Srbiji: izazovi i perspektive. Institut za pedagoška istraživanja, Ekonomski fakultet Univerziteta u Beogradu, ZUOV i ZVKOV, 69-70.

Rečnik srpskog jezika. [Dictionary of the Serbian language]. (2011). Izmenjeno i popravljeno izdanje. Nikolić, M.(ur.). Novi Sad: Matica srpska.

Sammons, P., Sylva, K., Melhuish, E., Siraj-Blatchford, I.,Taggart, B., Elliot, K. \& Marsh, A. (2014). The Effective Provision of Pre-School Education [EPPE] Project A longitudinal Study funded by the DfES (1997 - 2003). Institute of Education University of London. Retrieved from https://www.researchgate.net/publication/291938115 The Effective Provision of_PreSchool_Education_EPPE_project_a_longitudinal_study_funded_by_the_DfES_1997_-2003

Smieško Bokanić, O., Vučković, V., Skorić, N. \& Ivanović, J., priređivači. (2019). Preliminarna analiza Istraživanje stavova vaspitača i vaspitno obrazovne prakse u odnosu na Osnove obrazovanja i vaspitanja - Godine uzleta u PU "Radosno detinjstvo".

Šušnjić, Đ. (1973). Strukturalizam. Kritika sociološke metode. [Structuralism. Critique of the sociological method]. Niš: Gradina. Trebješanin, Ž. (2001). Rečnik psihologije. [Dictionary of Psychology]. Beograd: Stubovi kulture. 
Trivunović, B. (2017). Komunikacione kompetencije univerzitetskih nastavnika. [Communication competencies of university teachers]. Pedagoška stvarnost LXIII(2), 120-131. https://doi.org/10.19090/ps.2017.2.120-131

Uvod u usaglašavanje (TUNING) obrazovnih struktura u Evropi - doprinos univerziteta bolonjskom procesu. [Introduction to the harmonization (TUNING) of educational structures in Europe - the contribution of universities to the Bologna proces]. (2006). Projekat SOCRATES - TEMPUS. Retrieved from https://www.unideusto.org/tuningeu/images/stories/ documents/General_brochure_Serbian_version_FINAL.pdf

Vranješević, J. \& Trikić, Z. (2013). Kompetentan nastavnik/ca u kompetentnom sistemu - Srbija. [Competent teacher in the competent system - Serbia]. U: Vizek Vidović, V., Velkovski, Z. (ur.). Nastavnička profesija za 21. Vek, Unapređenje nastavničke profesije za inkluzivno, kvalitetno i relevantno obrazovanje-ATEPIE. Centar za obrazovne politike, 60-66.

Zakon o predškolskom vaspitanju i obrazovanju. [Law on Preschool Education]. (2019). "Sl. glasnik RS", br. 18/2010, 101/2017, 113/2017 - dr. zakon, 95/2018 - dr. zakon i 10/2019.

Zakon o osnovama sistema obrazovanja i vaspitanja. [Law on the Fundamentals of the Education System]. (2020)."SI. glasnik RS", br. 88/2017, 27/2018 - dr. zakon, 10/2019, 27/2018 - dr. zakon i 6/2020.

Zakon o visokom obrazovanju. [Law on Higher Education]. (2020). Sl. glasnik RS”, br. 88/2017, 73/2018, $27 / 2018$ - dr. zakon, $67 / 2019$ i 6/2020 - dr. zakoni.

Zlatković, B. \& Ristić, M. (2019). Implicitna uverenja vaspitača o prirodi deteta i mogućnostima razvoja. [Implicit beliefs of educators about the nature of the child and the possibilities of development]. Inovacije u nastavi, XXXII(4), 57-68. https://doi.org/10.5937/inovacije1904057z

Yusoff, M. (2009). Professional Behaviour: What Does it Means? Education in Medicine Journal, 1(1), 1-5. Retrieved from https://eduimed.usm.my/EIMJ20090101/EIMJ20090101_02.pdf

Žegarac, N., Kišjuhas, A. \& Koprivica, I. (2016). Pojmovnik kulturno-kompetentne prakse. [Glossary of culturally competent practice]. Novi Sad: Pokrajinski zavod za socijalnu zaštitu.

Živković, J. (2013). Društvo, odabrana poglavlja. [Society, selected chapters]. Niš: SVEN. 